\title{
UDLANDET TUR-RETUR SÅDAN FÅR MAN OGSÅ BØRN
}

\begin{abstract}
GOING ABROAD AND BACK | How do Danish women negotiate egg donation when it involves travelling to clinics in Spain or the Czech Republic? This article employs anthropological and sociological feminist literature on assisted reproductive technologies and transnational reproduction to understand the dynamics at play when Danish women travel to Spain or the Czech Republic for egg donation. The empirical material includes interviews with Danish women who are either planning to travel or who have already travelled for egg donation. The essay suggests that Danish women employ conventional understandings of both femininity and nationalized discourses. They mediate their border crossings not only as a type of gifting but also as a particular type of transnational service. Fertility travel is naturalized, in these discourses in light of the interviewees' desire to become mothers and, in the process, re-positioning transnational egg donation as a form of global sisterhood.
\end{abstract}

KEYWORDS | fertility travel, egg donation, globalization, motherhood, infertility

Efter flere års forsøg med fertilitetsbehandling og lange ventelister på ægdonation i Danmark valgte Kate og hendes mand at tage til Tjekkiet. Her var ingen ventelister og æggene stammede fra unge kvinder og derfor, siger parret, af "bedre kvalitet". Resultatet blev Anton, som med sit lyse hår og brune øjne da også, ler Kate, ligner både mor og far.

Denne artikel er en kulturanalyse af ægdonation og fertilitetsrejser til udlandet. Danske barnløse trodser i dag lange ventelister på ægdonation og tager til udlandet

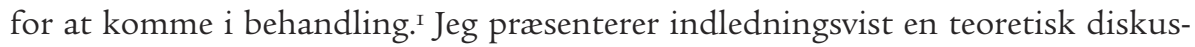
sion af forplantning som et globalt produkt, hvorefter jeg diskuterer metodiske og analytiske overvejelser forbundet med, hvordan danske rejsende "gør" moderskab. Det analytiske fokus er på danske fertilitetsrejsendes fortællinger og to centrale spørgsmål er derfor: Hvordan iscenesætter de rejsende ægdonation og en fertilitetsrejse til udlandet? Og hvordan "gør" de danske kvinder moderskab, når det er et resultat af ægdonation på en udenlandsk klinik? Det empiriske materiale understøtter den eksisterende viden om, at ægdonation overordnet nedbryder grænser

I Det er primært de lange ventelister i Danmark, som får barnløse til at tage til udlandet for at få ægdonation. Dog er aldersbegrænsningen for kvinden på 46 år samt det faktum, at barnløse ikke må benytte sig af både ægog sæddonation, også medvirkende faktorer. 
mellem genetik og miljø, samtidig med at behandling på den udenlandske klinik bliver begrebsliggjort i lyset af et forestillet globalt kvindeforplantningsfællesskab. At modtage et æg på en udenlandsk klinik bliver således iscenesat som både en gave, en vare og en "naturlig" ydelse. En fertilitetsrejse til udlandet bliver endvidere naturliggjort i lyset af selvbestemmelse og ønsket om moderskab, samtidig med at produktet af rejsen, ønskebarnet, iscenesættes som et helt igennem "eget” barn. Artiklen vil først præsentere en bredere teoretisk ramme og dernæst diskutere de måder, hvorpå danske kvinder forhandler og gør moderskab.

\section{Forplantning som globalt produkt}

Globale valgmuligheder positionerer den økonomisk ressourcestærke barnløse som en verdensborger på forplantningsmarkedet. Men hvad er egentlig i spil, når forplantning og kroppe krydser landegrænser? I dette afsnit præsenterer jeg en overordnet teoretisk ramme, idet jeg sætter fokus på skæringspunktet mellem globalisering og reproduktion og henter inspiration fra sociologien (Ehrenreich og Hochschild; Waldby og Cooper; Yeates), antropologien (Inhorn; Bharadwaj) og kulturanalysen (Stacey; Pollock).

Med begrebet globale omsorgskæder sætter Barbara Ehrenreich og Arlie R. Hochschild fokus på globalisering og omsorg som et stereotypt kønnet erhverv. Et centralt spørgsmål i deres arbejde er: Hvilke kroppe er det, som bevæger sig på tværs af landegrænser for at yde omsorg? Fokus er på de kønnede og klassemæssige relationer og de skævheder, som global bevægelighed kan skabe. Det kan være relationer mellem fattige kvinder fra Filippinerne, der drager til Vesten for at passe de børn, som man i Vesten ikke selv har tid til at passe, samtidig med at kvindernes egne børn nu må passes af andre (Hochschild).

Hochschild konkluderer, at denne globale bevægelighed geninstallerer patriarkalske og kolonialistiske opdelinger. Mens kvinder og mænd fra den første del af verden drager nytte af billige omsorgsydere, er det primært kvinder fra den tredje verden, der indgår som arbejdere i den globale omsorgsøkonomi (Hochschild). Globale skævheder naturliggøres, og Vesten bliver af Hochschild iscenesat som en patriark, der overfører det traditionelle og stereotype feminine omsorgserhverv nu til kvinder fra den tredje verden. Når begrebet anvendes på det globale marked i forplantning, er skævhederne også tydelige: Indiske rugemødre, der ved udlejning af en livmoder bliver positioneret som de ultimative omsorgsarbejdere i den globale forplantningsøkonomi (Pande).

Globale omsorgskæder kan med fordel sammenholdes med begrebet den globale produktkæde (Yeates). Hvor den globale produktkæde ikke i udgangspunktet har fokus på omsorg, så retter begrebet opmærksomheden mod en verdensomspændende distribuering og markedsføring, der forbinder virksomheder, arbejdere og forbrugere i en global konsumkultur. At forstå omsorg eller rettere i denne sammenhæng - forplantning - som et globalt produkt betyder, at de transnationale relationer mellem barnløse og donorer bliver iscenesat som et forhold mellem 
forbrugere og arbejdere, samtidig med at det skaber en kritisk forankring af Hochschilds begreb. Således er det ikke kun omsorgsøkonomien, som Yeates sætter fokus på men, argumenterer hun, også andre former for produkter og forbrug, der med fordel kan anskues med en global omsorgs- og produktoptik.

Marcia Inhorn repræsenterer en anden måde at begrebsliggøre globalisering og forplantning på. Inhorn henter sin inspiration fra feltarbejde på fertilitetsklinikker i Mellemøsten, samtidig med at hun forankrer det i antropologisk teori. I sit aktuelle arbejde videreudvikler hun Appadurais begreb om "scapes" til en slags "reproscapes", hvor såvel globale som lokale forplantningsaktører bliver synliggjorte. Samtidig peger hun dog også på begrebets mangler. Det var nemlig aldrig Appadurais formål, siger Inhorn, at sætte fokus på køn, ej heller på forplantning. Hun foreslår derfor i stedet begrebet "reproflow" som en mere dækkende betegnelse for både indre såvel som ydre bevægelser. Reproflow-begrebet kan synliggøre bevægelser, mener hun, herunder de måder, hvorpå kønsceller bevæger sig både i såvel som uden for kroppe samt de transnationale bevægelser, som barnløse, donorer, teknologier og det kliniske personale indgår i.

I modsætning til Hochschild ser Inhorn ikke globalisering som en entydig geninstallering af koloniale og patriarkalske praksisser. Således illustrerer hun, hvordan kombinationen af markedsmekanismer og vidt forskellig lovgivning på området er med til at producere nye bevægeligheder: eksempelvis unge hvide amerikanske middelklassekvinder, der flyver til Dubai for at donere deres æg. Inhorn udfordrer det lighedstegn, der ofte sættes mellem ægdonation og fattigdom, samtidig med at hun viser, hvordan markedsmekanismer kombineret med ret forskellig lovgivning på området er med til at producere bevægelser, der på interessant vis går på kryds og tværs af nationalitet og religion.

Jackie Staceys teoretiseringer udgør en anden kritisk tilgang til globalisering, der bygger på hendes baggrund inden for tværvidenskabelige studier, herunder køns- og kulturstudier. Stacey begrebsliggør det globale som performative effekter, og det er hendes pointe, at globalisering ikke fører til en denaturalisering af eksempelvis naturen, men i stedet til en renaturalisering og genfortryllelse af naturen: "To commodify nature is not to undermine its authority, but rather has quite the opposite effects"2 (I4O).

I hendes forskning bliver individuel sundhed, for eksempel, positioneret inden for nye typer af universalismer, som hører globaliseringen til: En ny-individualisme hvor Østens helbredelsesformer overføres til Vestens individualistiske retorik, samtidig med at nye konstruktioner af det universelle menneskelige subjekt opstår. Naturen genopfindes i det globale som det nye forbrugsgode. I Staceys optik går instrumentaliseringen af naturen hånd i hånd med konstruktionen af en ny global panhumanitet. De "andre naturer", herunder særligt tredje verdens naturer reciperes som konsumérbare lokaliteter, og det globale giver således fornemmelsen af en direkte adgang til en autentificeret natur. 
Formidlingen og markedsføringen af fertilitetsrejser indgår på mange måder i en sådan bevægelse. Indiske klinikker krydrer for eksempel en tur til Mumbai med en autentificeret indisk spiritualitet (små souvenirer og indiske guder), samtidig med at klienternes kulturchok begrænses ved hjælp af særlige indisk-vestlige overnatningssteder, chauffører og rejseguider (Kroløkke og Hvidtfeldt Madsen). Spanske fertilitetsklinikker kombinerer billeder af smilende mødre og nuttede spædbørn med et verdenskort, hvor barnløse selv kan klikke sig hen til den nærmeste klinik. Personificerede fertilitetsbehandlinger, søde og udadvendte mennesker samt et behageligt klima venter barnløse, hvis de vælger Spanien som fertilitetsdestination. Barnløses ønske om at få et barn iscenesættes i lyset af en indisk eller spansk kultur, hvor positionen som forældre har en fremtrædende (naturlig) plads, og derved bliver en rejse til udlandet, i hvert fald i markedsføringsmaterialet, renaturaliseret som noget af det mest selvfølgelige.

Hvor Hochschilds projekt i overvældende grad peger på, at globalisering geninstallerer velkendte magtpositioner, mener Inhorn, at globalisering fører til nye og ofte utilsigtede bevægelser. Endelig kan jeg ved hjælp af Staceys tværvidenskabeligt kulturanalytiske tilgang redegøre for, hvordan forplantning både bliver et globalt forbrugsprodukt, samtidig med at globalisering er en ressource såvel som en effekt. Mens Staceys teoretisering positionerer ægdonation og moderskab som en performativ praksis, så tydeliggør Inhorns tilgang de transnationale bevægelser, både hvad angår de danske rejsende, som fysisk bevæger sig til udlandet, og i overført betydning de måder, hvorpå ægget bevæger sig mellem forskellige kroppe, og de betydninger, ægget tillægges i de transnationale bevægelser. Jeg skal i det følgende kort præsentere det empiriske arbejde, der ligger til grund for artiklen, herunder metodiske overvejelser, samt supplere med en mere analytisk ramme, der har barnløses forhandlinger om moderskab som sit centrale omdrejningspunkt.

\section{Forplantningsrejser - metodiske og analytiske overvejelser}

Artiklen bygger på interviewmateriale med otte danske kvinder, der alle har været eller er på vej til udlandet for at modtage æg. De otte kvinder blev rekrutteret på baggrund af til dels en artikel om mit forskningsprojekt i Kimen, medlemsbladet for Landsforeningen for Ufrivilligt Barnløse, samt henvisning fra Trianglen, en privat fertilitetsklinik i Danmark.

Det er især destinationerne Tjekkiet og Spanien, som står på listen over de lande, hvortil danske barnløse rejser for at få ægdonation. Hvor de tjekkiske klinikker forsøger at adskille sig fra det centraleuropæiske og identificere sig med det mere "vesteuropæiske" (klinikker, hvor ekspertisen er i orden, lægerne taler både engelsk og tysk, og prisniveauet er overkommeligt), så markedsfører de spanske klinikker sig som kvalitetsklinikker med et internationalt netværk i ryggen. I deres visuelle udtryk forbinder klinikkerne fertilitetsbehandling på netop deres klinik med en global æstetik, herunder smukke, unge donorer og de perfekte børn og lykkelige mødre, der er resultatet af behandling. 
Det er ikke uvæsentligt, at private danske klinikker såsom Trianglen samarbejder med den spanske fertilitetsklinik IVI, og at netop IVI har klinikker i hele Spanien såvel som i Sydamerika. Således kan IVI iscenesætte sig selv som ikke alene en verdensomspændende fertilitetsklinik med et væld af donorer, men også som en attraktiv internationalt anerkendt destination. Tjekkiet såvel som Spanien er begge destinationer med direkte (og billige) flyruter fra både Billund og København, og af stor betydning er det også, at det er destinationer, som de barnløse ofte kender og føler sig trygge ved.

De otte interviews blev foretaget i perioden fra efteråret 2010 til efteråret $20 I I$ og fandt oftest sted i de interviewedes egne hjem. ${ }^{3}$ En uddybende præsentation af de interviewede, herunder informationer om deres alder, uddannelse, børn, seksualitet og ægteskabelige status samt fertilitetsdestination, findes i Appendiks I. Netop disse kategorier er betydningsfulde markører, om ikke andet så i forhold til den barnløses adgang til behandling. Hvor eksempelvis lesbiske og enlige kvinder i dag kan få fertilitetsbehandling i Danmark, så kræver ægdonation, at kvinden er under 46, samt at sæden kommer fra den mand, som er tiltænkt som far til barnet. Derfor får barnløse, som har brug for både æg- og sæddonation, ikke tilbudt behandling i Danmark. Endelig sætter økonomiske ressourcer ofte grænser for både destination og antallet af behandlingsforsøg; således er behandling i Tjekkiet betydeligt billigere end behandling i Spanien. ${ }^{4}$

Interviewmaterialet illustrerer, hvordan danske rejsende forhandler og "gør" moderskab. Den mere performative analytiske tilgang, som denne artikel ønsker at illustrere, flytter fokus fra det at vare mor til det at gøre mor. Et eksempel på netop den tilgang kan hentes i Della Pollocks analyser af kvinders fødselsfortællinger. Hun argumenterer, at kvinder bruger deres fødselsfortællinger som en måde at forhandle moderskab på, herunder oplevelser, der bevæger sig på grænserne mellem natur og kultur, liv og død samt nydelse og smerte. På tilsvarende vis påpeger jeg, hvordan ultralydsscanninger i løbet af graviditeten kan fungere som en symbolsk selviscenesættelse af positionen "den gode mor”. Ultralydsscanningen af den gravide bliver en medieret scene, hvorpå den kommende mor gør moderskab på en kulturelt genkendelig facon. Ligeledes er Charis Thompsons og Annemarie Mols metodiske og analytiske pointer centrale. Mens Mol præsenterer en metodisk ramme for, hvordan sygdom "gøres" af patienter såvel som i klinikkernes praksisser, argumenterer Thompson, at barnløse i deres selviscenesættelser af moderskab, graviditet og ny reproduktionsteknologi renaturaliserer biologi og genetik i lyset af intentionen om forældreskab.

I analysen vil jeg i det følgende kort diskutere ægget som grænseobjekt og de måder, hvorpå danske rejsende gør moderskab, dernæst vil interviewmaterialet blive perspektiveret i forhold til den bredere teoretiske ramme om globalisering og forplantning. Materialet illustrerer, at barnløse i tilegnelsen af et udenlandsk æg 
trækker på velkendte naturaliseringsstrategier (Thompson), samtidig med at det empiriske materiale med fordel også kan indskrives i en transnational kontekst.

\section{Agget som grcenseobjekt: gave, vare eller ydelse?}

Når kønsceller udtages og løsrives fra de kroppe, de kommer fra, indgår de, som Hochschild og Yeates også angiver, i en global kæde af distribuering og forbrug, samtidig med at de markedsføres i lyset af deres ophav herunder ofte kønnede og nationale forestillinger (Mamo; Nahman) og skifter betydning i bevægelserne mellem kroppe (Inhorn). Ægcellen er således både overskudsmateriale (noget som donoren ikke skal bruge), en gave (livets gave), et produkt (temperamentsfulde spanske gener eller musikalske slaviske aner), et investeringsobjekt (45.00o-75.00o kroner for én behandling), et barn, et fremtidigt forældreskab og en ydelse.

De etiske debatter samt den nuværende danske lovgivning på området problematiserer markedsmekanismerne, herunder kommercialisering af arveanlæg (Etisk Råd Kunstig Befrugtning Etisk Set). Det er særlig tydeligt i debatterne omkring ægdonation. Hvor mænd i lovgivningen og i debatterne omkring sæddonation bliver beskrevet som "naturligt" i stand til at befrugte mange kvinder og sprede deres gener, konstrueres kvindens æg som begrænset i antal og som en forlængelse af hendes identitet og krop (“ $Æ g$ er i langt højere grad end sæd en del af en kvindes krop og identitet” (26)). Således genfortælles en velkendt historie, hvor det maskuline (sæden) kædes sammen med det aktive, og det feminine (ægget) med det mere passive (Konrad). Hvor sæddonation naturliggøres som den "ældste” metode (I9), så skal æg hentes ud af kroppen og imiterer derfor ikke i samme grad den "naturlige" forplantning ("Kvinder kan ikke på naturlig vis overføre deres kønsceller" (25)). I de etiske debatter naturliggøres kønnede forskelle helt ned i de mikroskopiske celler. Hvor sæden bliver iscenesat som minimænd, bliver æggene minikvinder (Martin).

Ægdonation bevæger sig på grænsen til det monstrøse (Pollock, Complicating Power). Som flere af de rejsende også selv bider mærke i: "Hvis kvinder spreder deres gener. Det er bare ikke fint" (Line). At donere sine muligheder for at blive gravid er potentielt en overskridende handling. Derfor må ægdonation nødvendigvis positioneres i en kulturel ramme, som betoner det altruistiske, og på den måde geninstalleres det feminine (Pollock, Complicating Power). Det altruistiske er da også i hovedsædet, når udenlandske klinikker præsenterer ægdonation. Spanske IVI beskriver eksempelvis ægdonation som:

"The donor delivers her ova (eggs) which will be brought together with spermatozoa, and the embryos resulting from this will be transferred to the receptor woman, who will thus fulfill her wish thanks to the anonymous and unselfish help of another woman."s (IVI España, "Ovum Donation") 
I IVIs fremstilling udgør den altruistiske ramme en genkendelig og acceptabel kulturel ramme, som eliminerer eventuelle monstrøse potentialer. Og det til trods for det faktum, at de spanske donorer modtager en økonomisk kompensation på ca. 900 Euro (Velasco). Kønsforskeren Monica Konrad begrebsliggør det altruistiske i lyset af feministisk teori: "Whether women's bodies are regarded as sources of substance-augmentation or substance-extraction, female bodies are collapsed discursively into ones of natural femininity/innate altruism”6 (65I). Mens altruisme i IVI's ovenfornævnte citat illustrerer Konrads pointe, så er også flere andre konstruktioner i spil. Ægdonoren er i citatet positioneret som en anonymiseret, men dog aktiv "leverandør" af en genetisk pakke rettet mod en modtager, som er konstrueret i en mere passiv og tilnærmelsesvist maskinel position som "receptor", samtidig med at teknologien, der muliggør ægdonation, bliver gjort usynlig.

At forstå ægdonation på en udenlandsk klinik alene som enten en gave eller som en vare er dog problematisk. Donorer såvel som modtagere trækker nemlig på begge rammer og strategier, samtidig med at ægdonation i højere grad bliver positioneret i en tredje kategori - som en ydelse. Mens for eksempel spanske ægdonorer peger på både det altruistiske og det økonomiske som motivation for deres beslutning om at donere (Orobitg og Salazar), så er begge fortællinger også betydningsfulde for de rejsende.

De danske rejsende anvender i høj grad den altruistiske konstruktion i deres tilblivelsesfortællinger, samtidig med at de ønsker, at ægdonoren bliver kompenseret for sit "arbejde". Kate omformulerer eksempelvis datterens tilblivelsesfortælling til "En sød dame hjalp mor med at få dig” (Kate), samtidig med at hun betoner, at donorens "indsats" skal udmøntes i en "ordentlig” økonomisk kompensation (interview med Kate, august 20II). Agdonorens nationalitet er her af mindre betydning. Det er i stedet den økonomiske kompensation, der i den fortælling skaber en form for transnational gensidighed og udvisker nationalitetsforskelle. Derudover sætter Kate lighedstegn mellem ægdonorens indsats og sine egne tidligere hormonbehandlinger, hvorved ægdonation bliver positioneret som et "arbejde" eller en "service", som endvidere sætter Kate i stand til at tilegne sig og opleve æggene som "sine".

Agdonation omskrives fra at være en altruistisk handling til en "ydelse". Som Line bemærker: "Vi køber ikke æg, vi køber behandling" (Line). Den økonomiske kompensation skaber ifølge de rejsende en gensidighed donor og modtager imellem, samtidig med at det nødvendige indgreb herunder hormonbehandlinger og de teknologiske processer er usynliggjorte. Ægdonoren leverer "pakken", men har ingen intentioner om moderskab og bliver i den forplantningskæde en "leverandør". Æggene tilhører ikke den kvinde, som det kommer fra, men er snarere en "ydelse". Den økonomiske transaktion giver den rejsende mulighed for at positionere donation som en form for nødvendig assistance - uden dog at positionere donoren

6 "Uanset om kvinders kroppe betragtes som kilder til at kunne forøge eller udvinde substanser, så bliver kvindekroppen diskursivt kædet sammen med det naturlige kvindelige/en slags medfødt altruisme.” 
i kategorien mor, samtidig med at altruisme anvendes til at producere den gode tilblivelsesfortælling - en vigtig fortælling ikke bare for klinikkerne og de kommende forældre, men også i forhold til det kommende barn.

\section{Mellem mor og ikkemor}

I interviewene giver flere af kvinderne udtryk for at foretrække ægdonation (frem for adoption), netop fordi ægdonation giver dem en mulighed for at "gøre graviditeten", samtidig med at de bliver indskrevet i et fællesskab af "normale" gravide. I Staceys optik kan vi sige, at ægdonation i udgangspunktet denaturaliserer det genetiske moderskab, men at de rejsende i deres fortællinger positionerer graviditet, fødsel og amning som grundlæggende elementer i moderskabskonstruktionen, og derved renaturaliserer de også ægdonation i henhold til princippet om mater semper certa est-moderen ved man altid hvem er.

Det er derfor ikke overraskende, at de udenlandske klinikker og de rejsende betoner både graviditet og fødsel i deres fortællinger. Spanske IVI Barcelona søger eksempelvis at gøre donorægget til den modtagende kvindes eget æg så tidligt som muligt. Således lader de donorægget hvile i væske udtaget fra den danske kvindes krop - en praksis, der på det allertidligste stadie signalerer intention, ejerskab og håb.

Det er dog ikke den eneste måde, hvorpå de udenlandske klinikker og de kommende forældre gør donorægget til den modtagende kvindes. Af særlig stor betydning er visualiseringen af de(t) befrugtede æg og ultralydsscanningen af ægget på vej ind i kvindekroppen. Lone reflekterer over det i forhold til de to befrugtede æg, som hun kun få dage før vores interview har fået lagt op:

"I virkeligheden da jeg så det. Man ser jo de der to ... det var så to æg eller to ... det er jo ikke kun æg ... det var to æg, der blev lagt op, og man ser det ... den ene var seks celler og den anden syv celler, og det er meget fint. Da følte jeg da... De er mine. I skal blive til noget. Nu skal jeg passe på Jer to, der kommer op i mig” (Lone).

I fortællingerne er visualiseringen startskuddet på en eventuel graviditet, og på at modtagerkvinden nu kan "passe på” æggene - og derved allerede gøre moderskab ("I skal blive til noget"), samtidig med at visualisering af de befrugtede æo giver ejerskab ("de er mine”) og er startskuddet på en ny tilblivelseshistorie. I dette reproflow bevæger det befrugtede æg sig som et grænseobjekt mellem donorkroppen og modtagerkroppen, mens det retorisk konstrueres af både den rejsende og af klinikkerne i lyset af den modtagende kvindes krop (Thompson).

På den måde indgår klinikkernes praksisser og her særligt ultralydsscanningen på interessant vis $\mathrm{i}$ både en af- og renaturalisering af moderskab. Som flere af kvinderne bemærker, er der ikke megen kærlighed eller seksualitet forbundet med assisteret befrugtning, men det er et særligt privilegium at "se" sine fremtidige børn på et tidligt stadie: "Jeg synes faktisk, at hvis de eller det ene bliver til noget, 
så synes jeg, det er ret fantastisk at have set dem" (Lone). At have set "dem” på det absolut mindste niveau giver de rejsende en anden måde at gøre forældre på.

Det befrugtede æg bliver en repræsentant for det kommende barn og er med til at skabe en position som forældre. Det er også tilfældet for flere af mændene: Lars insisterer for eksempel på at være til stede, når æggene bliver lagt op:

"Det var faktisk også meget vigtigt for mig at se, når æggene bliver lagt op i Anne. Det var... (griner) ... det var det tætteste, jeg kom på at befrugte hende for nu at sige det ligeud" (Lars).

Det at se æggene blive lagt op giver kvinden en fornemmelse af, at de er "hendes", samtidig med at Lars i dette tilfælde også kan indgå i en aktiv position som "befrugter”. Mens Lars allerhelst så hele processen forbundet med æggets befrugtning, inklusive det øjeblik hvor æg og sæd mødes, så er visualiseringen med til at skabe en fælles historie og positionerer ham mere aktivt i processen. Flere af mændene stiller sig da heller ikke tilfredse med en passiviseret position som "sæddonor" og bemærker i stedet:

"Det er lidt specielt for mig at sige ... nå, jamen nu ligger der et eller andet på frost dernede, og du behøver ikke engang at komme med derned, Lars ... det er sådan set lige meget" (Lars).

Visualisering på det allertidligste stadie rekontekstualiserer natur/kultur-distinktionen, herunder de kønnede relationer. Lars er i det ovenfornævnte eksempel ikke kun en gang "optøet sæd" - han er en "befrugter" og fremtidig far.

De interviewede tilpasser endvidere ægdonation i udlandet med genkendelige strategier om slægtskab. Det delte blodomløb, de spæde spark, fødslen og amningen fungerer som en måde at skabe om end ikke et genetisk slægtskab - så et biologisk slægtskab på (Thompson). Undfangelsen sker i fortællingerne i forlængelse af, at det befrugtede æg sætter sig fast i den kommende mors livmoder. Som Line bemærker, bliver det kommende barn formet af den gravide, og derfor er barnet, siger hun, et helt igennem eget barn. At Lines krop får tilskrevet en aktørrolle, indskriver hende som en "naturlig" mor til barnet.

Skønt ægdonation på mange måder skaber nye måder at få børn på, så bliver de biologiske relationer ikke dekonstrueret - snarere kommer de styrket ud af fortællingerne (Thompson; Franklin). Som anført af flere af de interviewede, er det stadig uvist, hvilke betingelser der skal være opfyldt, for at et æg sætter sig fast. I den uvished indgår modtagerkroppen som aktør, og donorkroppen positioneres som et ophav til det nødvendige genetiske materie men på ingen måde som en moderkrop. Line siger: "Der er jo flere og flere, som mener, at det kan påvirkes, så hvis det (det befrugtede æg) blev lagt tilbage i donoren, så ville det ikke nøjagtig blive det samme barn.” På lige fod med de par og individer, der vælger ægdonation i Danmark, sætter de rejsende også fokus på graviditeten, fødslen og den "moderlige” omsorg. 
I de fortællinger får den rejsendes krop en betydningsfuld aktørrolle i skabelsen af et "eget" og helt unikt "vores" barn, samtidig med at visualiseringsteknologien rekontekstualiserer natur- og kulturdimensionen og er med til at "gøre" barnløse til kommende forældre.

\section{Fra tabt til ny kvindelighed}

Ægdonation skaber ikke alene nyt liv, men blæser også nyt liv i de rejsendes kvindelighed. Dårlig ægkvalitet er, siger de, en grundlæggende udfordring for deres selvforståelse og her særligt deres identitet som sunde og aktive kvinder. Med Staceys optik vil jeg argumentere, at de udenlandske klinikker og de rejsende positionerer ægdonation som en form for pan-femininitet: Et forestillet globalt forplantningsfællesskab, hvor smukke eller i hvert fald smilende spanske eller tjekkiske kvinder gennem ægdonation giver den tabte natur (fertilitet) tilbage til danske barnløse kvinder.

Spanske IVI trækker netop på ideen om et globalt kvindefællesskab, når de i deres markedsføringsmateriale, som også før anført, skriver at den rejsende vil få sit ønske opfyldt: "thanks to the anonymous and unselfish help of another woman” (IVI España, "Ovum Donation”).7 Forskellene modtager og donor imellem er i citatet reduceret til et spørgsmål om frugtbarhed, samtidig med at ægdonorens altruistiske motiver naturliggøres og bliver autentificeret i lyset af en spansk altruistisk-orienteret kultur (Simon). Nationalitets- og klasseforskelle opløses, og ønsket om moderskab geninstalleres i markedsføringsmaterialet som et helt naturligt ønske. Agget er her ikke en form for stand-in for en anden (spansk eller tjekkisk) kvindes identitet, men ægget er snarere global materie og frugtbarhed, som bevæger sig mellem kvinder og mixes i henhold til intentionen om moderskab (Thompson; Inhorn).

Mens dele af kønsforskningen positionerer ægdonation som en kannibalistisk handling (Scheper-Hughes), så iscenesætter de danske kvinder i højere grad ægdonation som en form for foryngelseskur. Det biologiske ur sættes på standby, og den tabte kvindelighed genvindes. Fertilitetsbehandlingerne, som de alle har været underlagt - at blive kunstigt sat i overgangsalderen for at frigive "de sidste æg” - kan de nu lægge bag sig. Flere af de interviewede tilkendegiver derfor, at de er "lettede" over, at det nu er en ung kvindes æg, som de venter på. Ægdonation fra en yngre kvinde er med til at genskabe en "normal" kvindelighed. Som Rita, der $\mathrm{i}$ en alder af 5I og efter endt behandling på IVI Barcelona siger:

"Med hensyn til det med at være gammel og føde. Det er æggene, der er problemet. Alt det andet er jeg god til. Jeg har ammet nu i 8 måneder, så ja ... jeg synes i hvert ikke, at det er af den grund, man skal forhindre kvinder ... jeg har ikke ligget systemet til last. Det var fuldstændig, som da jeg var 32. Det gik faktisk bedre” (Rita). 
I den fortælling adskiller ægdonation sig ikke væsentligt fra andre og tidligere tiders sygdomsbehandlinger, der manipulerer, eller som Nikolas Rose påpeger det, "optimerer" og "forbedrer" kroppen. I fortællingerne er kvindernes kroppe måske godt nok "gamle", men de er nu ved hjælp af ægdonation "frugtbare", og derved får kvinderne deres tabte kvindelighed tilbage. Som Rita bemærker det, så går den kropslige præstation da heller ikke ubemærket hen: "det var fandeme godt gået”, var kommentaren fra jordemoderen efter hendes fødsel. Når frugtbarhed således ikke længere "er i æggene”, flytter kvinderne frugtbarhed til graviditet, fødsel og amning.

\section{Den "naturlige" selvbestemmelse}

I de barnløses fortællinger afløses evolutionsteoriens forståelse af forplantning den naturlige udvælgelse af den "naturlige selvbestemmelse". Den naturlige selvbestemmelse vedrører den barnløses forståelse af graviditet og moderskab som en "ret", herunder retten til at vælge behandling, donor, klinik og donorland. Et større udvalg af donorer gør, at man for eksempel i Spanien kan matche modtager og ægdonor. Dertil kommer et decideret lovkrav i Spanien om, at man skal matche de kommende forældre og donor mest muligt. Hvor den danske rejsende oplever det som en højere grad af selvbestemmelse, er formålet i den spanske kontekst dog også at kunne hemmeligholde donation. De danske rejsende ser muligheden for at kunne matche en donor som en klar fordel. Om valgmulighederne i Spanien siger Lone eksempelvis, "når det nu ikke bliver mig, så må det da gerne ligne mig" (Lone). Derfor er valgmulighederne betydningsfulde om end også lidt uvante, eller som Jane udtrykker det på baggrund af sit første besøg på den spanske klinik:

"Så siger vi hårfarve, og så fordi at jeg nogen gange er mere rødhåret og sådan noget, men jeg er egentlig mørkebrun, så det er mørkebrun, ikke. Og øjenfarve er jo selvfølgelig blå, men min kæreste har grønne, så der er åbenbart mange også med grønne øjne dernede, så jeg sagde sådan blå øjne som nummer et, grønne øjne som nummer to, og ellers er det fuldstændig lige meget, så tager vi de brune (griner)” (Jane).

Flere af de interviewede udtrykker, at de må genforhandle deres ønske om "eget" barn på ny, når ægdonation foregår på en udenlandsk klinik. For flere af dem er det simpelthen "for mærkeligt" eller "for sært" at forestille sig, at et barn med anden hårfarve eller for den sags skyld hudfarve eller et særlig "grimt” barn skulle komme ud af "deres” krop. Som Jane om sit besøg på den spanske klinik siger:

"De sidder simpelthen og spørger og kigger på mig. Har du light skin, har du dark skin? Så siger jeg nej... jeg kan godt blive meget brun, men vi må sige light skin, for ellers bliver det jo sådan noget” (Jane). 
Den "naturlige" forplantning imiteres i klinikkernes praksisser og her konkret i valget af donor, som når denne matches i forhold til eksempelvist øjenfarve, hårfarve og hudfarve.

De rejsende ønsker ikke bare et barn - de ønsker også et barn, som "ligner dem”, både hvad angår udseende og værdier. Når det nu ikke kan lade sig gøre i Danmark, vælger de et land, som de enten har en tilknytning til, eller som de som minimum føler sig trygge ved. Line har således valgt Spanien som donorland med begrundelsen: "Jeg har altid følt mig hjemme i Spanien" (Line). Og tilsvarende har Kate og hendes mand skabt en fortrolighed med Tjekkiet gennem deres private rejser til området (Kate og Kurt).

Når donorerne er anonyme, bliver spanske eller tjekkiske kvinder, som de rejsende møder i eksempelvis Prag eller Valencia og under deres besøg på klinikkerne, interessant nok en form for stand-ins for den egentlige donor. Som Anne og Lars siger om deres ankomst til Prag:

"Da vi så var, da vi så kom til Prag der første gang ... nu det er mange år siden, at jeg har været i Prag ... så gik jeg bare sådan rundt og kiggede på alle kvinder ... nej ... hvor er I smukke. Det var dog helt fantastisk. I smiler, hvor er I søde. Fedt nok, bare gi’ mig Jeres æg. Altså, jeg skulle lige ha' den der dimension med ...” (Anne)

"Du sagde faktisk dernede flere gange ... hende derovre, hun må godt aflevere æg. Det sagde du faktisk til flere kvinder eller ikke til kvinderne, men (griner) men ... men sagde det til mig. Hun må godt aflevere ... Det hørte jeg som værende ... Jeg kan godt forestille mig, at det som de her har af udseende, man kunne se der og den adfærd, de udstrålede, det det vil du gerne stå for” (Lars).

Forestillinger om donoren er på den måde tæt tilknyttet forestillinger om donorland - de menneskelige egenskaber samt udseende. Hvor Anne eksempelvis var lidt skeptisk over Tjekkiet som donorland grundet "gamle" forestillinger om mindre attraktive tjekkiske kvinder (indskrevet i en østeuropæisk kontekst), var den første rejse til Prag med til at rykke ved hendes forforståelse. Tilsvarende vælger Jane at tage til Spanien - ikke alene fordi hun betragter Spanien som et mere "civiliseret" land (i skarp kontrast til Østeuropa), men også fordi hendes farver matcher, siger hun, det spanske:

"Efterfølgende har jeg tænkt lidt over, at der tit er nogen, som har spurgt mig, om jeg stammede fra Spanien, fordi mine farver og sådan lidt hvor jeg tænker egentlig mig ... men om sommeren kan jeg godt blive ret brun, og så har jeg sådan lidt mørke bryn og når så håret bliver afbleget, så er det åbenbart lidt spansk i farverne. Og det har jeg bare studset over efterfølgende, at det var egentlig sjovt” (Jane).

Klinikkerne benytter sig i den henseende også af en dobbeltstrenget formidlingsstrategi: De er både udbydere af behandlingsmuligheder og af gode arveanlæg, der sikrer det bedst mulige barn og den største sandsynlighed for graviditet. Endvidere 
indskriver de sig i en europæisk kontekst som indehavere af gode (europæiske) værdier og som historiske bidragydere til europæisk kultur. Tjekkiske klinikker trækker eksempelvis på historiske og elegante byer (som Prag) samt en placering "i hjertet af Europa" (Your IVF Vacation), mens IVI Barcelona positionerer sig som en moderne by med verdensomspændende attraktioner og Gaudís værker (IVI España), og de spanske klinikker i øvrigt positionerer sig i lyset af smukke strande, tapas og spansk gæstfrihed.

Formidlingen afløses dog også af et fokus på graviditet og miljø, som strategisk geninstallerer den kommende mor som den "naturlige" mor. Således bliver Janes udtrykte bekymring for at modtage et æg fra en storryger nedtonet, og i stedet er det hendes sundhed, som tæller. I den fortælling er de danske rejsende ikke positioneret som "rugemødre", men snarere gennem graviditet og deres stærke ønske om få et barn "rigtige" mødre. Genetikken bliver erstattet med biologi og selvbestemmelse, som ikke alene sikrer et barn - men et barn, der til trods for at det har spanske eller slaviske aner, stadig "ligner".

\section{Globalisering og forplantning - opsamling}

Fertilitetsrejser og ægdonation på udenlandske klinikker vidner på én gang om globalisering og nye forplantningsruter, samtidig med at ægdonation bliver begrebsliggjort som et bevægeligt grænseobjekt. Jeg vil afslutningsvis først diskutere, hvordan de rejsende i fortællingerne iscenesætter sig selv som centrale aktører i selve skabelsesbeslutningen samt de måder, hvorpå grænserne mellem kultur og natur både bliver afmonteret og genfortalt. Dernæst vil jeg diskutere fertilitetsrejser i lyset af den bredere teoretiske kontekst.

I fortællingerne er det den kommende forælders intention om moderskab eller forældreskab - selve skabelsesbeslutningen, som er i centrum. Som flere bemærker: "Det var mig som traf beslutningen”, "jeg rejste til Tjekkiet", "hvis det ikke havde været for mig, var min datter ikke blevet født"; eller som anført af Rita, der her refererer til sin nu otte måneder gamle datter: "En ægcelle og en sædcelle er blevet til i en petriskål, fordi jeg har ringet til lægen og sagt, at jeg vil forfærdelig gerne have hende" (Rita). Skabelsesbeslutningen er altså her helt tildelt de barnløse.

Men det er ikke kun selve beslutningen; det er også den "heroiske" kamp om at blive forældre, som er betydningsfuld. En kamp, som på mange måder bliver understøttet af den rejse, som de barnløse er "tvunget" til at foretage:

"Kampen for ... hvis vi når dertil, og så kan man sige ... nogen gange så tænker jeg, at jeg elsker allerede det barn, som ikke engang er ... for jeg har sgu gennemgået så mange processer i mit hoved" (Line).

Skabelsesbeslutningen tillægges den barnløse og her ikke alene, hvad angår det faktum, at en ægcelle og en sædcelle mødte hinanden i en petriskål, et embryon 
blev til et foster og til et barn gennem den voksende gravide krop, men også det faktum, at selve undfangelsen var den barnløses beslutning, kamp og rejse.

Det empiriske materiale illustrerer, hvordan de rejsende, også i tråd med den tidligere forskning i øvrigt, afmonterer genetikken og i stedet geninstallerer biologi og intention som den ny natur (Bestard; Franklin). I fortællingerne er arbejdet fordelt mellem flere forskellige aktører: Den spanske eller tjekkiske ægdonor leverer den genetiske pakke (leverandør), den (måske) kommende far leverer sæden, det kliniske personale mixer æg og sæd, og visualiseringen af de befrugtede æg giver ejerskab og forældreskabet tilbage til de rejsende. Forældreskab forrykkes fra det genetiske til biologien, den individuelle selvbestemmelse og teknologien.

Tilbage til den bredere teoretiske kontekst og til Ehrenreich og Hochschild's mere kritiske tilgang kan jeg afslutningsvis spørge: Hvilke globale omsorgsrelationer (u)synliggøres, når danske barnløse rejser til udlandet for at få æg? Det er meget synligt, at en fertilitetsrejse iscenesættes i forlængelse af den barnløse som et "aktivt" subjekt. Når barnløse krydser landegrænser for at få de børn, som de mener, de har ret til at få, indskriver de sig i en allerede genkendelig position som handlekraftige individer, samtidig med at de skaber nye ruter for produktion og konsumption af forplantning. De barnløse "googler" sig frem til en - for dem - god men også ofte uigennemsigtig behandlingsløsning. Agdonation bliver i den proces omskrevet til en serviceydelse og en optimering af en ufrugtbar krop, samtidig med at selve rejsen bliver en heroisk transformation - en rejse fra barnløs til frugtbar, hvor nationalitets- og klasseforskelle opløses.

Globale omsorgskæder er med til at sætte kritisk fokus på, hvordan omsorgsrelationer altid er gennemsyret af magt. Begrebet er særlig anvendeligt i kritikken af den voksende fertilitetsindustri og de forbindelser, som skabes mellem eksempelvis danske og spanske eller tjekkiske klinikker samt rekruttering af donorer. I de barnløses fortællinger er det dog interessant, at magtrelationer modtager og donor imellem udjævnes. De rejsende betoner en forestillet "gensidighed": På den ene side er donoren positioneret som en viljestærk og empatisk ung spansk eller tjekkisk kvinde, samtidig med at hendes økonomiske motivation strategisk nedtones, men omvendt og på interessant vis bliver denne også opprioriteret i tilegnelsen af barnet som et "eget" barn. Det er dog den altruistiske ramme, som indgår som en rød tråd i de rejsendes tilblivelsesfortællinger.

Nationalitets- og klasseforskelle og derved æggets potentielle andethed bliver i fortællingerne nedtonet. De rejsende positionerer i stedet ægget i lyset af materie og frugtbarhed, der (naturligt) bevæger sig mellem spanske/tjekkiske og danske kvinder. Såvel de interviewede som klinikkerne iscenesætter den ideelle donorkvinde som et "match" med modtagerkvinden, og således opløses potentielle race-, nationalitets- og klasseforskelle. På den måde undgår de interviewede og klinikkerne at indlejre en fertilitetsrejse i en bredere politisk kontekst og væver det i stedet sammen med en verden, hvor global bevægelighed er en helt naturlig forlængelse af den barnløses selvbestemmelse og ønske om et barn. 
Når kroppe bevæger sig på tværs af landegrænser for at få opfyldt, hvad de beskriver som deres største ønske, så skifter også ægget betydning. Det er både overskudsmateriale og nødvendige arveanlæg, både gave, vare og ydelse. Behandlingen iscenesættes nu ikke længere i lyset af det "unaturlige" forbundet med ægdonation i udlandet, men snarere i lyset af den "naturlige" længsel efter et barn. Donorbørnene har måske nok en genetik med rødder i for eksempel det spanske eller det slaviske, men det menneskelige og sågar det biologiske ophav er et langt stykke hen ad vejen tilskrevet den kvinde, som har båret barnet. Intention, længsel og beslutning gør barnløse til "rigtige" forældre, samtidig med at visualisering, graviditet, fødsel og amning gør donorbørn til "egne” børn - også når det foregår i udlandet.

\section{Appendiks I: Interviewpersoner}

\begin{tabular}{|c|c|c|c|c|c|c|}
\hline Navn* & Alder & Uddannelse & Børn & Seksualitet & $\begin{array}{l}\text { Egteskabe- } \\
\text { lige status }\end{array}$ & Destination \\
\hline Rita & 52 & $\begin{array}{l}\text { Lang uddan- } \\
\text { nelse }\end{array}$ & $\begin{array}{l}\text { Voksen } s ø n \text { og dat- } \\
\text { ter ved ægdonation }\end{array}$ & Heteroseksuel & Enlig & Spanien \\
\hline Anne samt Lars & 42 & $\begin{array}{l}\text { Mellemlang } \\
\text { uddannelse }\end{array}$ & Ingen & Heteroseksuel & Samlevende & Tjekkiet \\
\hline Line & 35 & $\begin{array}{l}\text { Mellemlang } \\
\text { uddannelse }\end{array}$ & Ingen & Heteroseksuel & Gift & Spanien \\
\hline Ruth & 42 & $\begin{array}{l}\text { Mellemlang } \\
\text { uddannelse }\end{array}$ & Ingen & Heteroseksuel & Gift & Spanien \\
\hline Kate samt Kurt & 42 & $\begin{array}{l}\text { Mellemlang } \\
\text { uddannelse }\end{array}$ & $\begin{array}{l}\text { To børn, begge ved } \\
\text { hjælp af ægdona- } \\
\text { tion. Datter født } \\
\text { ved hjælp af ægdo- } \\
\text { nation i Danmark } \\
\text { og søn ved hjælp } \\
\text { af ægdonation i } \\
\text { Tjekkiet }\end{array}$ & Heteroseksuel & Gift & $\begin{array}{l}\text { Danmark/ } \\
\text { Tjekkiet }\end{array}$ \\
\hline Tyra samt Keld & 42 & $\begin{array}{l}\text { Mellemlang } \\
\text { uddannelse }\end{array}$ & Søn & Heteroseksuel & Gift & Spanien \\
\hline Lone & 32 & $\begin{array}{l}\text { Lang uddan- } \\
\text { nelse }\end{array}$ & Gravid & Heteroseksuel & Samlevende & $\begin{array}{l}\text { Danmark/ } \\
\text { Spanien }\end{array}$ \\
\hline Jane & 45 & $\begin{array}{l}\text { Lang uddan- } \\
\text { nelse }\end{array}$ & Ingen & Heteroseksuel & Kæreste & Spanien \\
\hline
\end{tabular}

* Alle navne er ændrede og består af fire bogstaver

Tak til Forskningsrådet for Kultur og Kommunikation, som har støttet projektet. 


\section{LITTERATURLISTE}

Appadurai, Arjun. Modernity at Large: Cultural dimensions of globalization. Minneapolis: University of Minnesota Press, 1996.

Bestard, Joan. "Kinship and the new genetics. The changing meaning of biogenetic substance". Social Anthropology I2, 3 (2004): 253-263.

Bharadwaj, Aditya. "Biosociality and biocrossings: encounters with assisted conception and embryonic stem cells in India". Biosocialities, Genetics and the Social Sciences. Making biologies and identities. Red. S. Gibbon og C. Novas. Oxon: Routledge, 2008: 98-II6.

Ehrenreich, Barbara og Arlie R. Hochschild. Global Woman: Nannies, Mads, and Sex Workers in the New Economy. New York: Metropolitan, 2003.

Franklin, Sarah. Embodied progress: A cultural account of assisted conception. London: Routledge, 1996. Hochschild, Arlie R. "The Nanny Chain”. The American Prospect 30. november 2002.

Hoeyer, Klaus. "Person, patent, property: A critique of the commodification hypothesis". BioSocieties 2, 3 (2007): 327-348.

Inhorn, Marcia. "'Assisted' motherhood in global Dubai: Reproductive Tourists and Their Helpers". The Globalization of Motherhood: Deconstructions and reconstructions of biology and care. Red. J.M. Maher og W. Chavkin. New York: Routledge, 20IO: I80-202.

IVI España. Den 28. februar 20I2. 〈http:www.ivi.es〉.

IVI España, "Ovum Donation". Den 28. februar 20I2. <http://www.ivi.es/en/treatment/ovadonation_20.aspx>.

Konrad, Monica. "Ova Donation and Symbols of Substance: Some Variations on the Theme of Sex, Gender and the Partible Body". Journal of Royal Anthropological Institute 4, (2000): 643-667.

Kroløkke, Charlotte. "Biotourist Performances: Doing Parenting during the Ultrasound". Text and Performance Quarterly 3I, I (20II): I5-36.

Kroløkke, Charlotte og Karen Hvidtfeldt Madsen. "Også respektabel? Retoriske konstruktioner af fleksible (u)frugtbare kroppe”. Rhetorica Scandinavica 56 (2010): 3I-48.

Mamo, Laura. Queering Reproduction. Achieving Pregnancy in the Age of Technoscience. Durham: Duke University Press, 2007.

Martin, Emily. "The Egg and the Sperm: How Science Has Constructed a Romance Based on Stereotypical Male-Female Roles”. Signs: Journal of Women in Culture « Society 16, 3 (I99I): 485-50I.

Mol, Annemarie. The body multiple: ontology in medical practice. Durham: Duke University Press, 2002.

Nahman, Michal. "Materializing Israeliness: Difference and mixture in transnational ova donation". Science as Culture 15, 3 (2006): 199-213.

Orobitg, Gemma og Carles Salazar, C. "The Gift of Motherhood: Egg Donation in a Barcelona Infertility Clinic" Ethnos 70, I (2005): 3I-52.

Pande, Amrita. "Commercial Surrogacy in India: Manufacturing a Perfect Mother-Worker". Signs: Journal of Women in Culture \& Society 35, 4 (2010): 969-992.

Pollock, Anne. "Complicating Power in High-Tech Reproduction: Narratives of Anonymous Egg Donors". Journal of Medical Humanities 24, nos 3/4 (2003): 24I-263.

Pollock, Della. Telling Bodies, Performing Birth. Everyday Narratives of Childbirth. New York: Columbia University Press, 1999. 
Rose, Nikolas. Livets politik. Biomedicin, magt og subjektivitet i det 2I. århundrede. Dansk Psykologisk Forlag, 2009.

Scheper-Hughes, Nancy. "Organ Trade: The New Cannibalism”. The New Internationalist April, (I998): I4-I7.

Stacey, Jackie. “The Global Within. Consuming Nature, Embodying Health”. Global Nature, Global Culture. Red. Sarah Franklin, Celia Lury, Jackie Stacey. Los Angeles, London: Sage Publications, 2000: 97-I45.

Thompson, Charis. Making Parents. The Ontological Choreography of Reproductive Technologies. Cambridge: The MIT Press, 2005.

Velasco, Juan Garcia. "Egg Donation in Spain. The Spanish Point of View”. The European Society of Human Reproduction and Embryology maj 2007: 26-30.

Waldby, Catherine og Melinda Cooper. "The Biopolitics of Reproduction. Post-Fordist Biotechnology and Women's Clinical Labour”. Australian Feminist Studies 23, 55 (2008): 57-73.

Yeates, Nicola. "Global Care Chains: critical reflections and lines of enquiry”. International Feminist Journal of Politics 6, 3 (2004): 369-39I.

Your IVF Vacation. Den 28. februar 20I2. 〈http:www.yourivfvacation.cZ〉. 
DETTE MATERIALE ER OPHAVSRETSLIGT BESKYTTET OG MÅ IKKE VIDEREGIVES 